\title{
GRAVITY INVERSION OF THE ONSHORE POTIGUAR BASIN BASEMENT RELIEF: SIMULATING RESULTS ASSOCIATED WITH DIFFERENT EXPLORATORY PHASES
}

\author{
Marina B. Gaino ${ }^{1,3}$, Julio Cesar S.0. Lyrio² and Walter E. Medeiros ${ }^{3,4}$
}

\begin{abstract}
Gravity inversion results aiming to estimate the crystalline basement relief of the onshore Potiguar Basin are presented. It is assumed that the density contrast between the sediments and the crystalline basement is constant and known. The sediments are approximated with vertical rectangular prisms whose thicknesses, representing the depths to crystalline basement, are the parameters to be estimated from the gravity inversion. In all cases, the inversion process was stabilized with smoothness constraint on the spatial variation of the basement relief. Besides the gravity data, we used information about the basement relief obtained from boreholes and from seismic interpretation. These data were combined in order to compose three different scenarios simulating different phases during the exploratory development of the basin. In the first scenario we used the gravity data only. In the second scenario we worked with two combinations, first we combined the gravity data with information from boreholes, and second, with the basement relief reference model that resulted from the seismic interpretation. Finally, in the third scenario, we used the gravity data, the information from the boreholes and the reference model obtained from the seismic interpretation. In all scenarios, we obtained reliable estimates for the basement relief. Concerning the discrepancies among the results, the estimates obtained with additional constraints (from boreholes and/or seismic interpretation) increased the overall resolution of the basement relief and the reliability of the absolute depth values. However, it is important to stress that the first scenario already yielded a reliable estimate to the basin relief. If one takes into account the huge difference both in financial cost and environmental impact associated with gravity and seismic surveys, respectively, as well as with borehole drilling, this result highlights the great importance of properly using the gravity data in the initial exploratory phase of the basin.
\end{abstract}

Keywords: gravity inversion, basement relief, Potiguar Basin, constrained inversion.

RESUMO. Este trabalho apresenta aplicações de inversão gravimétrica para a estimativa do relevo do embasamento cristalino da Bacia Potiguar emersa. Admite-se que 0 contraste de densidade entre os sedimentos e o embasamento da bacia é constante e conhecido. 0 pacote sedimentar é aproximado por um conjunto de prismas lateralmente justapostos cujas espessuras, ou profundidades até o embasamento, são os parâmetros a serem estimados na inversão. Em todos os casos, o processo de inversão foi estabilizado com o uso do vínculo de suavidade na variação espacial do relevo do embasamento. Além das medidas gravimétricas, foram utilizados dados de poços e/ou oriundos da interpretação sísmica, em diferentes combinações, de modo a simular diferentes etapas, ou cenários, de exploração da bacia ao longo do tempo. No primeiro cenário foram utilizados somente dados gravimétricos. No segundo cenário, simulamos duas situações, em ambas adicionando outras informações aos dados gravimétricos: na primeira delas, adicionamos somente vínculos de poços e, na segunda, apenas um modelo sísmico de referencia para 0 embasamento. Por fim, no último cenário foram agregados aos dados gravimétricos os dados de poços e o modelo sísmico. As estimativas obtidas para o relevo do embasamento revelaram nitidamente 0 arcabouço da bacia em todos os cenários. Em relação às variações das profundidades entre os cenários, as inclusões dos vínculos dos poços e do modelo sísmico aprimoraram a resolução global dos resultados, como esperado. Contudo, é relevante destacar que a inversão no primeiro cenário já forneceu um relevo bastante aproximado do arcabouço conhecido da bacia. Se levarmos em conta as grandes diferenças de custo financeiro e de impacto ambiental, respectivamente associados com os levantamentos gravimétrico e sísmico, bem como com a perfuração de poços, esse resultado evidencia a grande importância de uma adequada utilização dos dados gravimétricos nas fases exploratórias iniciais de uma bacia.

Palavras-chave: inversão gravimétrica, relevo do embasamento, Bacia Potiguar, inversão vinculada.

\footnotetext{
1PETROBRAS/UO-RNCE/EXP/ABIG, Av. Euzébio Rocha, 1000, Cidade da Esperança, 59070-660 Natal, RN, Brazil. Phone: +55(84) 3235-3855; Fax: +55(84) 3235-3237

- E-mail: marina@petrobras.com.br

2PETROBRAS/E\&P/GEOF/MnS, Av. República do Chile, 330, Torre Leste, $11^{\circ}$ andar, Centro, 20031-170 Rio de Janeiro, RJ, Brazil. Phone: +55(21) 2144-1867

- E-mail: jlyrio@petrobras.com.br

${ }^{3}$ Graduate Program in Geodynamics and Geophysics (PPGG/UFRN), Department of Geophysics, Universidade Federal do Rio Grande do Norte, Centro de Ciências Exatas e da Terra (CCET/UFRN), Lagoa Nova, 59072-970 Natal, RN, Brazil. Phone: +55(84) 3342-2502 (ramal 205) - E-mail: walter@geofísica.ufrn.br

${ }^{4}$ INCT-GP, Instituto Nacional em Ciência e Tecnologia em Geofísica do Petróleo (CNPq), Brazil, at: http://www.cnpq.br/
} 


\section{INTRODUCTION}

The gravimetric inversion is a tool that can be used to estimate the relief of an interface between two homogeneous media such as, for example, the basement relief of a sedimentary basin. However, this is a mathematically ill-posed problem due to the instability of the solutions. The usual way to rectify this problem is to minimize the functional, to adjust the gravity observations while incorporating constraints to the problem to stabilize its solution (e.g. Barbosa et al. (1999) and other references cited in this article).

This paper uses gravimetric inversion to estimate the basement relief of the onshore Rio Grande do Norte Basin. It is assumed that the density contrast between the sediments and the basement is constant and known, and an effective or average density value was used (Litinsky, 1989). The sedimentary pack is approximated by a set of vertical prisms juxtaposed laterally whose thicknesses or depths up to the basement are the parameters to be estimated in the inversion. The problem is stabilized with the smoothness constraints on the spatial variation of the basement relief and proximity to reference and/or known values, Barbosa et al. (1997, 1999) and Lyrio (2009).

In addition to the gravimetric measurements, borehole and/or seismic interpretation data were also used in different combinations, to simulate three different scenarios or stages of exploration in the basin over time. In the first scenario, the model used as input in the inversion is flat, in order to simulate complete lack of knowledge about the basin relief. In the second scenario, we have two options: the availability of borehole data or seismic reference model. Finally, in the last scenario, the basement reference seismic model is aggregated to the inversion process, coupled with information from the boreholes that reached the basement and those completed in the sedimentary section. The aim of this study is to investigate how the estimates of the basement relief change with the advancement of the exploratory phase, thus showing the benefits of applying the gravimetric inversion method at different stages.

The paper is organized as follows. First, we will summarize the gravimetric inversion techniques used, and then present a synthesis of the structural framework of the onshore Potiguar Basin, as well as a description of all data used and the composed scenarios, and finally, we will discuss the results of the inversion for each scenario, followed by a comparative analysis.

\section{GRAVIMETRIC INVERSION}

The used gravimetric inversion technique is based on the study of Barbosa et al. $(1997,1999)$ on using smoothness constraints on the spatial variation of the basement relief and the proximity to known basement depth values from boreholes that reached the basement, for example. Operationally, we use the algorithm developed by Lyrio $(2002,2009)$, which extends the previous results to also include constraints of unequal depths, associated with sites where the boreholes did not reach the basement. Mathematically these constraints are introduced in the form of logarithmic barriers (Lyrio 2002, 2009).

The sedimentary section is discretized into a set of juxtaposed and regular vertical prisms, whose thickness at each point is the depth to be estimated using the gravity field measured on the surface. It is assumed that the prisms have constant density (Litinsky, 1989), tops coincident with the Earth flat surface and regular spacing, equal to the mesh resulting from the interpolation of gravimetric data.

The algorithm used requires the knowledge of the residual gravity anomaly as a regular grid, the density contrast between the sediments and the basement, of a reference model for the basement relief, as well as control parameters associated with the stabilizing solution process. Information regarding boreholes, including those that did not reach the basement, may also be used. The regularization parameters used in the inversion algorithm were tested empirically in order to provide, simultaneously, good fit of the gravimetric data, solution stability and a reasonably short computational time. Parameters were kept constant for all inversion scenarios.

\section{STRUCTURAL FRAMEWORK OF THE ONSHORE POTIGUAR BASIN}

The onshore Potiguar Basin is cretaceous and was implemented during the separation process of the South American and African plates (Matos, 1987). This basin is currently in a mature phase of its oil exploration that began in the mid-1970s. Therefore, from the point of view of exploration, it is assumed that the basin is well known, particularly its crystalline basement relief.

The structural framework of the onshore basin (Fig. 1) is defined by half-grabens and NE-SW internal highs, sandwiched between shallow basement platforms, defining an asymmetric rift of rhombic shape (Matos, 1987). The Potiguar rift is chambered in half-grabens aligned in NE-SW direction and tilted to SE, Soares et al. (2003). These semi-grabens are bordered to the E-SE by the alignment of the Carnaubais faults (NE-SW), whose tailings are variable and may reach $5 \mathrm{~km}$, constituting the faulted edge of the basin. Opposite, the flexural zone is associated with the Areia Branca Hinge, where the tailings are smaller and less significant. 


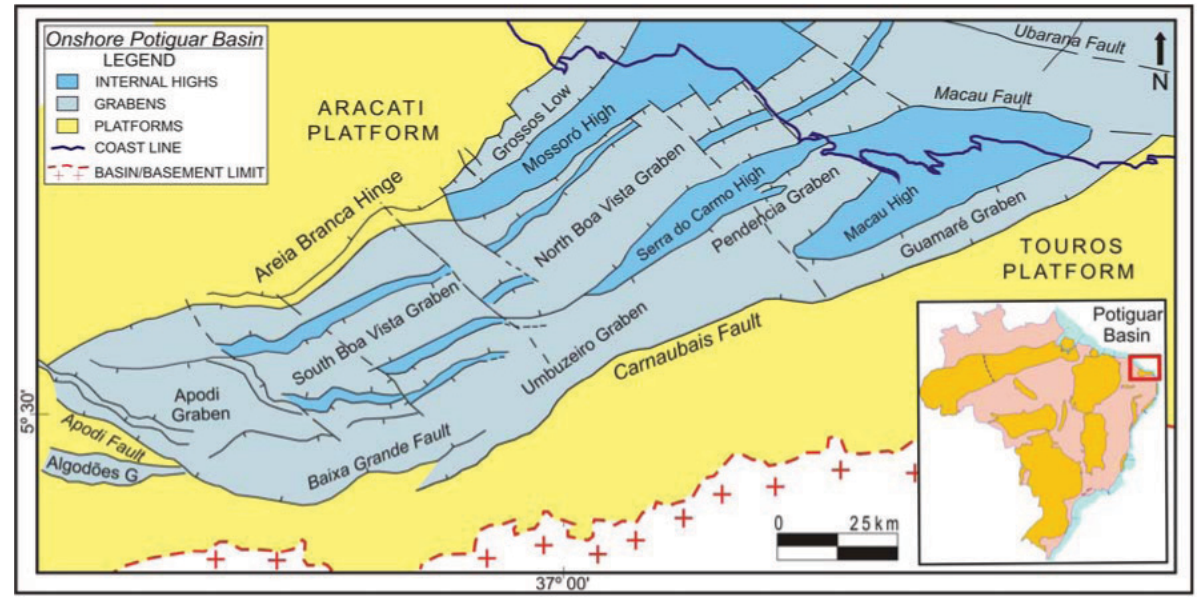

Figure 1 - Structural framework of the onshore Potiguar Basin highlighting the main rift. Modified from Soares et al. (2003).

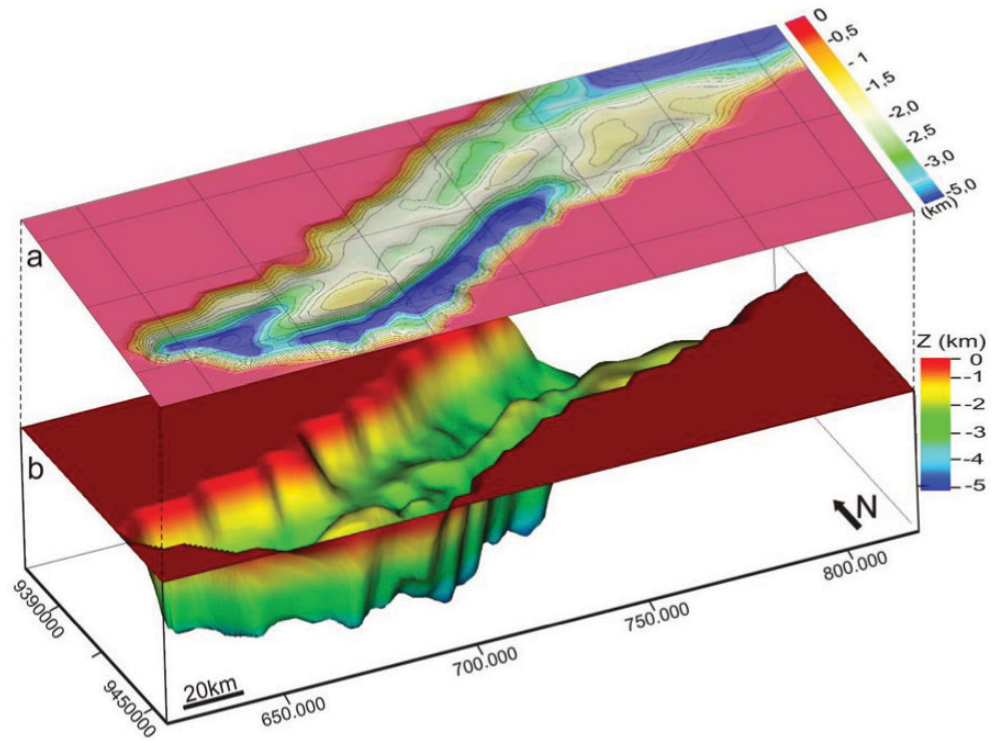

Figure 2 - Basement of the onshore Potiguar Basin obtained from the seismic depth map prepared by Matos (1992): a) contour map, and b) Perspective view with vertical exaggeration $8 \times$.

In turn, the NW-SE trending Apodi fault defines the S-SW boundary of the rift.

Although the NE-SW direction is prominent in the framework of the onshore Potiguar Basin, it is noteworthy the presence of another NW-SE alignment system, associated with the Afonso Bezerra fault system, which cuts orthogonally both the basin and the basement (Oliveira et al., 1993).

Geological details of the Potiguar Basin, including its stratigraphy, can be found in Pessoa Neto et al. (2007).

\section{USED DATA AND SCENARIOS}

In this work, we use a reference model for the basement depths resulting from seismic interpretation, borehole information about depth and gravity data. All data are associated with the onshore portion of the Potiguar Basin, except for the gravity data which included a slightly wider area (not shown), including the sea, to provide better definition of the regional and residual gravity fields. The onshore area comprises a rectangle of about $120 \times 230 \mathrm{~km}^{2}$ and encompasses the entire rift of the basin.

Figure 2 shows the reference model for the basement, which was built from the digitization of seismic structural map presented by Matos (1992) derived from the 2D seismic interpretation. Note that this model (Figs. 2a and 2b) reproduces very well all the structures shown in Figure 1. Also note that, for simplicity, we assume that the thickness of the sedimentary column is zero in the region outside the rift. 

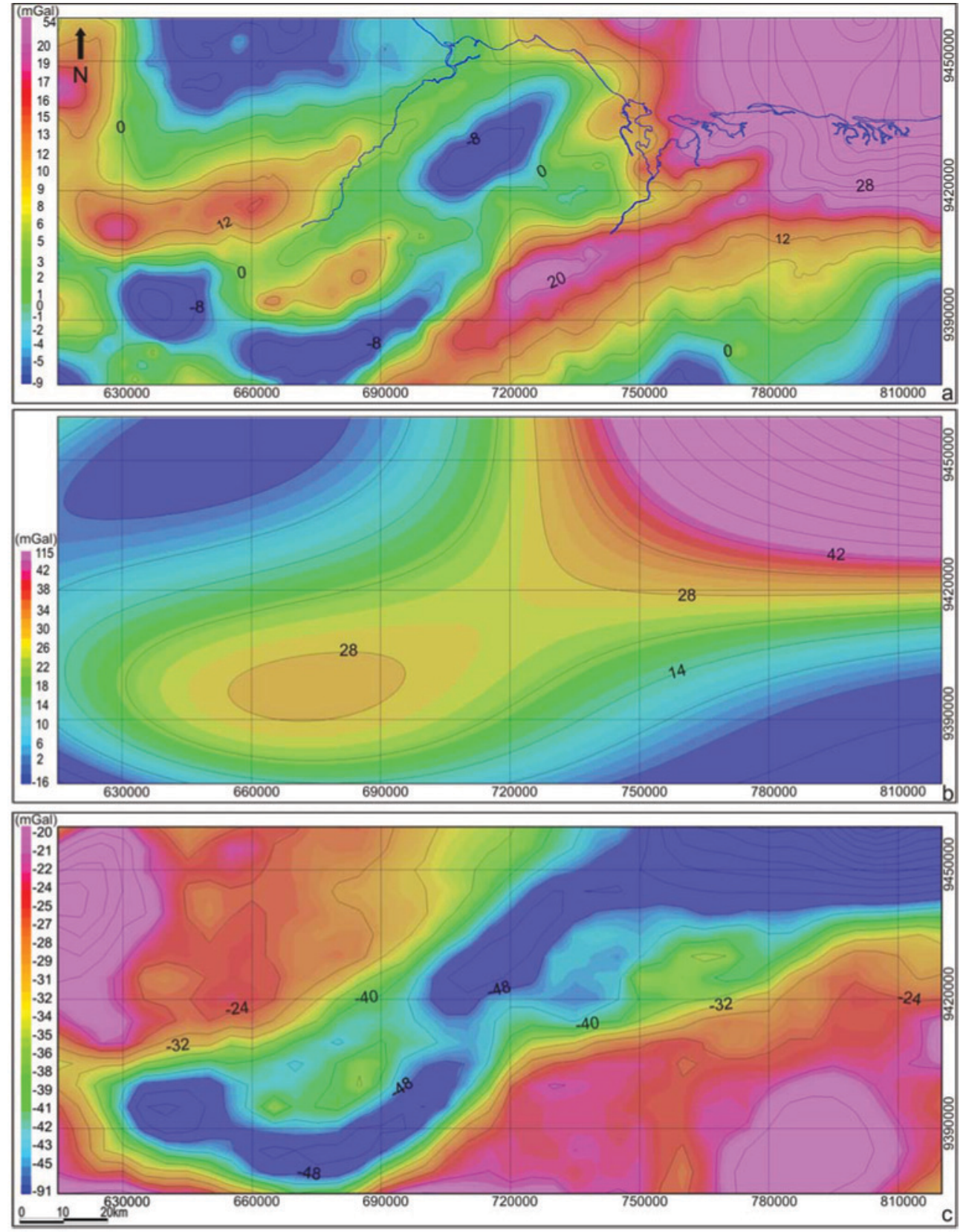

Figure 3 - Maps of the onshore Potiguar Basin: a) Bouguer anomaly (contour interval of 4 mGal and coast blue line), b) regional gravity anomaly obtained from the $4^{\text {th }}$ order polynomial fit (contour interval of $\left.7 \mathrm{mGal}\right)$, c) residual gravity anomaly (contour interval of $4 \mathrm{mGal}$ ).

Constraints on the depths of twenty-three boreholes that reached the basement, together with the information from five boreholes ending in the sedimentary section were added to the inversion process.

The gravity data used in this work originated from the database of the Universidade Federal do Rio Grande do Norte, Brazil, which aggregates different gravimetric stations and covers the entire Borborema Province and adjacent areas. These data were previously treated by Oliveira (2008), who standardized all gravimetric corrections.

The gravimetric measurements were interpolated onto a regularly spaced grid with $5-\mathrm{km}$ squares on each side, resulting in a set of 756 prisms for the gravimetric inversion process. Figure 3a shows the resulting Bouguer field. Its separation into regional and residual components (including surrounding areas) was performed by the robust polynomial adjustment method of 

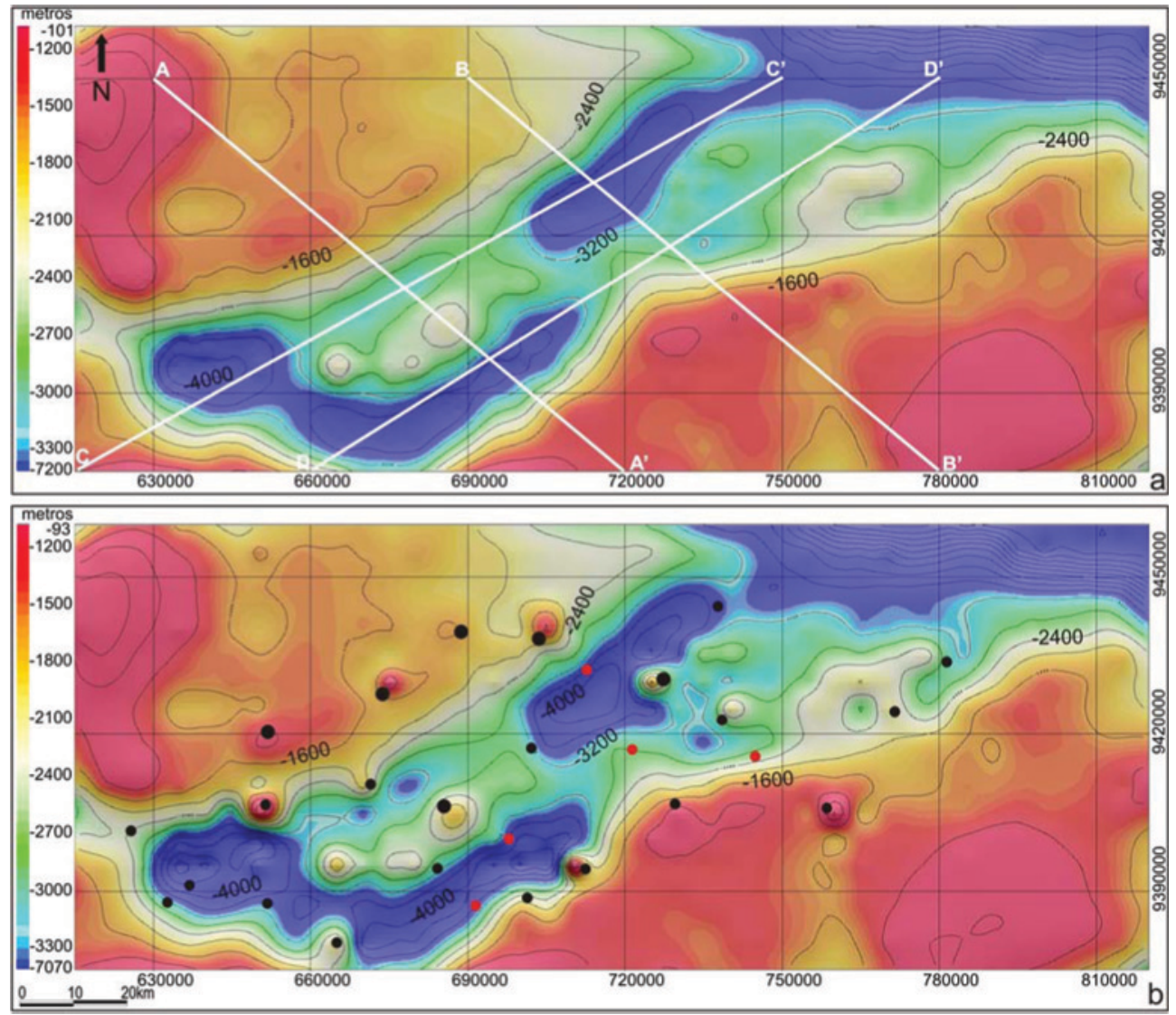

Figure 4 - Estimated basement relief of the onshore Potiguar Basin resulting from gravity inversions performed: a) Scenario 1 and b) Scenario 2a. Also shown (a) location of profiles A-A', B-B', C-C' and D-D' in Figure 6, and (b) position of boreholes (black circles for the wells that reached the basement and red for wells ending in the sedimentary section) circles. Contour interval of $400 \mathrm{~m}$.

Beltrão et al. (1991). The $4^{\text {th }}$ order polynomial was chosen to represent the regional component (Fig. 3b), resulting in the residual field shown in Figure 3c.

The effective density contrast (Litinsky, 1989) between sediments and basement was assumed constant and equal to $-0.37 \mathrm{~g} / \mathrm{cm}^{3}$. This value resulted from a series of inversion tests (with different density contrasts obtained from boreholes), in which the maximum depths of the basement were about $6 \mathrm{~km}$, a reasonable limit to the maximum depth allowed for the basin.

The data described above were used in different combinations to simulate three different scenarios or basin exploration stages over time.

In the first scenario (Scenario 1), only the residual gravity field and an estimated density contrast are known, while a flat reference model is used as input to the inversion. Thus, a complete lack of knowledge about the basin relief is assumed, so that this first scenario would simulate an initial phase of its exploration process.
The second scenario analyzes two situations: the additional availability of borehole data (Scenario 2a), or a seismic reference model for the basement (Scenario 2b), thus reproducing intermediate exploration stages of the basin. Finally, in the third scenario (Scenario 3), the seismic reference model is added to the inversion process, as well as information from boreholes, including those that have not reached the basement. This scenario, therefore, simulates a very advanced exploration stage of the basin. The aim of this study is to investigate how the basement relief estimates change over time as the exploration advances, thus showing the benefits of applying the method of gravimetric inversion at different stages.

\section{RESULTS AND DISCUSSION}

Estimates of the basement relief of the onshore Potiguar Basin associated with scenarios $1,2 \mathrm{a}, 2 \mathrm{~b}$ and 3 are presented as contour lines in Figures $4 a, 4 b, 5 a$ and $5 b$, respectively. In order to 


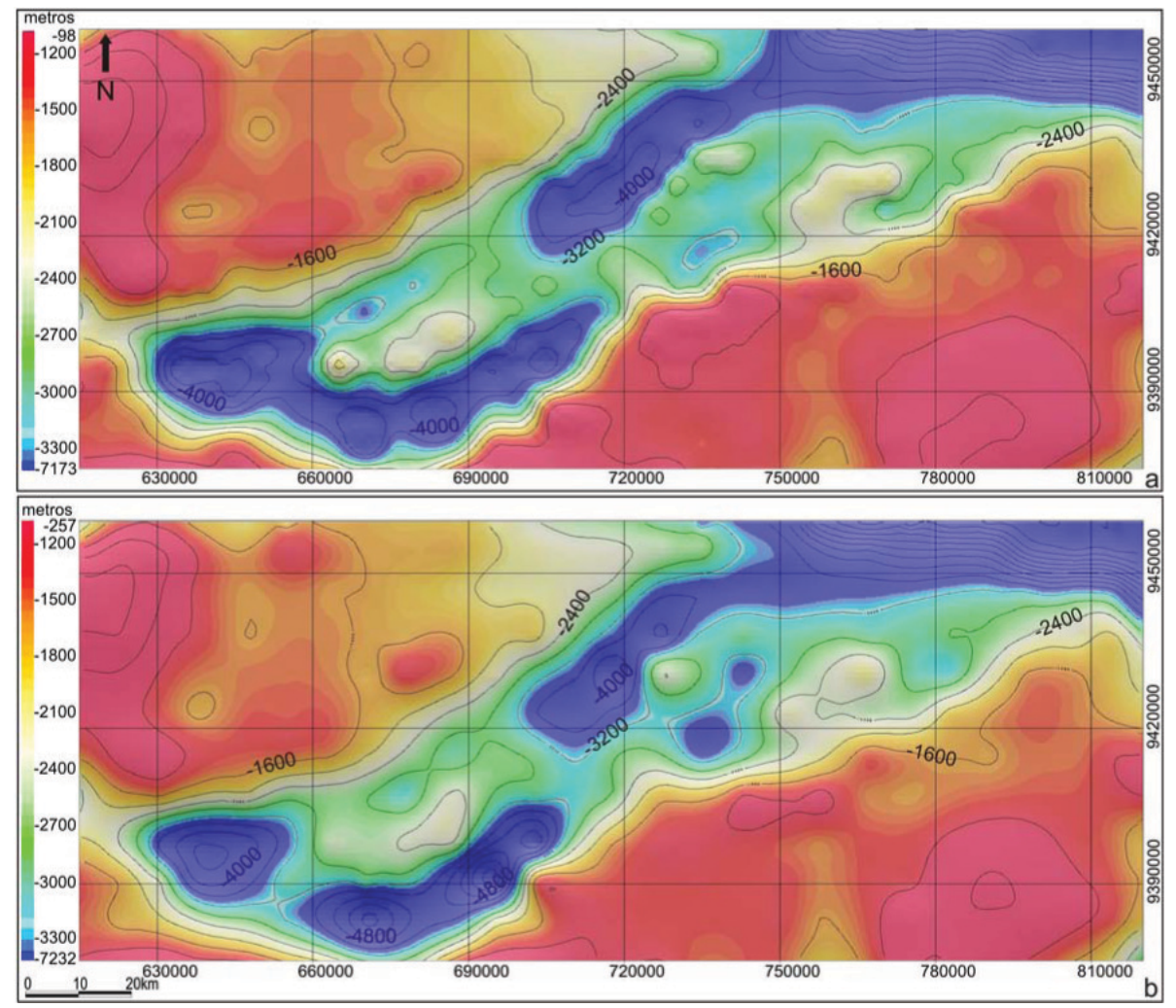

Figure 5 - Estimated basement relief of the onshore Potiguar Basin resulting from gravity inversions performed: a) Scenario 2b, b) Scenario 3. Contour interval of $400 \mathrm{~m}$.

facilitate viewing and comparing the results, the same estimates are also shown: (1) together as profiles strategically placed along the NW-SE (Figs. 6a and 6b) and NE-SW (Figs. $6 c$ and $6 d$ ) trending areas; (2) as maps and their views in perspective for each scenario (Figs. 7-10). Figure 7a also exhibits the used gravimetric measurements to provide the reader with an analysis of consistency and compatibility between the resolution obtained for the basement relief and the set of measurements. Figure 8a shows the boreholes aggregated into the inversion process, twenty-three wells (black circles) completed in the basement and five wells (red circles) completed in the sedimentary section.

The adjusted fields in all scenarios are not presented; however, they all satisfactorily reproduce the residual gravity field (Fig. 3c).

In general, estimates of basement relief for all scenarios show the internal geometry of the onshore Potiguar Basin. It is noteworthy that the resulting model in Scenario 2a shows some spurious features - in the form of pinnacles - associated with the borehole positions (Figures 4b, 8a and 8b). The most likely explanation for these is that they reflect too strong constraints to the depths of the wells. However, the possibility that some of these wells are located on the edges of faults where abrupt depth changes occur, which are incompatible with the softness constraint imposed, cannot be ruled out.

Regarding variations in basement depth, it is noted mainly through the profiles (Figs. 6a, 6b, 6c and 6d) that, as the constraints are applied, the aggregate information increases the complexity level of the basement relief. Since these solutions are stable, we can relate, at least as first approximation, the increasing complexity in the basement relief with increased resolution (except for the previously mentioned spurious features). The relief obtained in Scenario 3 (red lines in Figs. 6a-6d) is certainly the most reliable as it resulted from the reference model for the basement (derived from seismic interpretation), calibrated with borehole depths.

Subsequently, the comparative analysis of the results is going to be detailed. The first noteworthy observation from the results is that the gravimetric inversion in Scenario 1 has already provided a very good overview of the basement relief geometry (Figs. 4a, 7a and $7 \mathrm{~b}$ ). Note that this estimate was performed using only gravity 
data, with a regional spacing grid (Fig. 7a). The stabilization of the results comes only from the use of smoothness constraints on the spatial variation of the relief. However, the major structural features of the basin are evident (compare Figs. $7 \mathrm{~b}$ and 1).

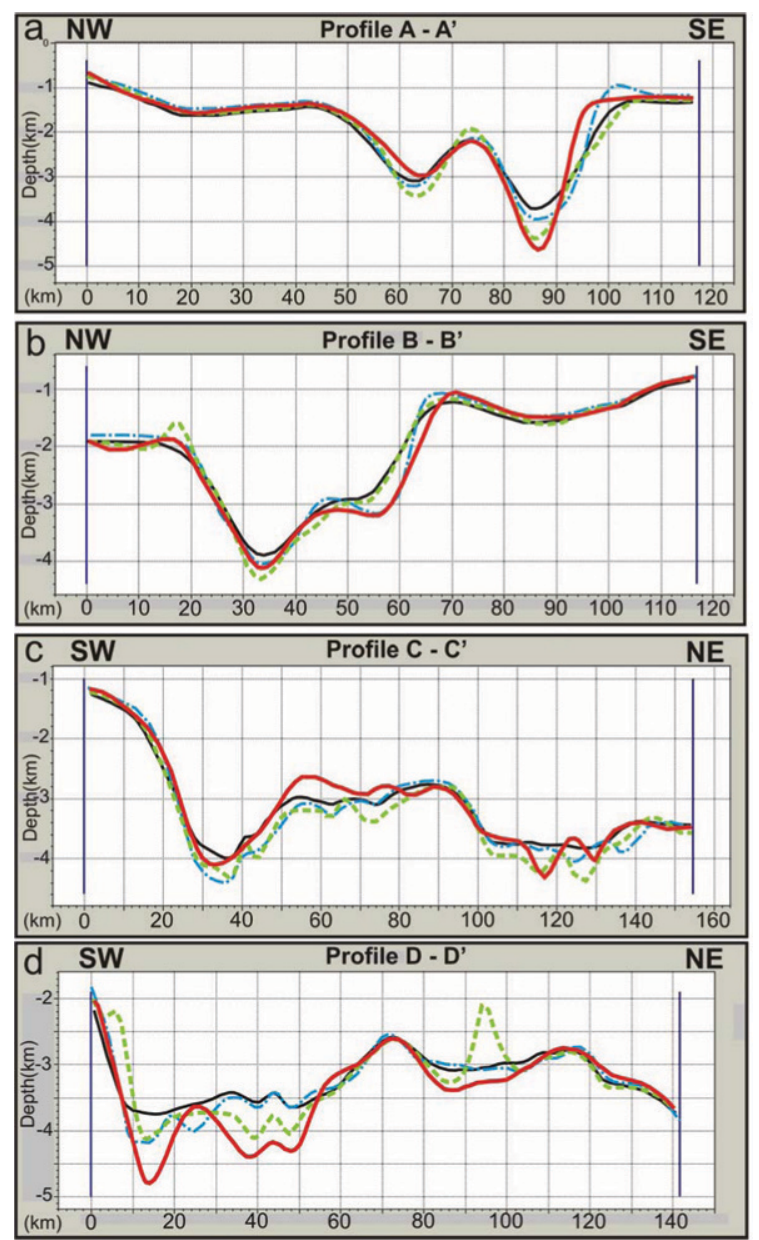

Figure 6 - Profiles of estimated basement relief resulting from gravity inversions of the onshore Potiguar Basin: a) Profile A-A' (NW-SE), b) Profile B-B' (NW-SE), c) Profile C-C'(SW-NE), and d) Profile D-D' (SW-NE). Legend: Scenario 1 (solid black line), Scenario 2a (dotted green line), Scenario 2b (dotted blue line), and Scenario 3 (solid red line). The location of the profiles is shown in Figure 4a. Note that the vertical and horizontal scales are different for each profile.

The inclusion of the depth data (derived from boreholes) in the gravimetric inversion of Scenario 2a gives, in general, a deeper estimation of basement relief (Figs. 4b, $8 a$ and $8 b$ ), when compared to the inversion of Scenario 1 (Figs. 4a, 7a and 7b). However, as already noted, the resulting model has a few "pinnacles" coincident with the borehole positions, especially those completed in the basement (Figs. 8a and 8b).

In Scenario $2 b$, the introduction of the seismic reference model for the basement (Figs. 2a and 2b) in the gravimetric inversion gives an estimation (Figures 5a, 9a and 9b) with some- what deeper reliefs compared to inversion of Scenario 1 (Figs. 4a, $7 \mathrm{a}$ and $7 \mathrm{~b})$. This result could be refined, taking into account the limitations of seismic interpretation, due to loss of quality of definition of the reflectors mainly in the deeper portions of the rift.

Finally, the estimated basement relief obtained from the gravimetric inversion in Scenario 3, provided not only a very good view of the basin framework (Figs. 5b, 10a and 10b), but also exhibited relief depths more consistent with the reference model, compared to previous results. This holds true not only in the deep regions of the basin but also in the shallower portions, which we believe, are virtually close to the actual features in the subsurface.

Noteworthy are the discrepancies in relation to the reference model (Figs. 2a and 2b) of the estimates obtained in Scenarios $2 b$ and 3 (Figs. 9b and 10b), as illustrated in Figures 11a and $11 c$, respectively. The surfaces of the differences between the two estimates and the input model (Figs. 11b and 11d) allow us to conclude that the relief estimates are very similar to the seismic model, and generally deeper. However, in the central-southeast region of the Carnaubais fault (Fig. 1), aligned positive anomalies are observed, confirming that in this area the resulting estimates are relatively shallower than the seismic model (pink arrows in Figs. 11b and 11d).

These results suggest two hypotheses. The first, considering the seismic model more accurate (that is, the best match to the actual basement relief), acknowledges that the discrepancies for the estimated gravity models could reflect possible variations of the density contrast between the sediments and the basement, or intra-basement variations of density. On the other hand, if the gravimetric model is more coherent (i.e., it is the best match to the true basement relief), then the seismic reference model contain inconsistencies that would distort the results. There are several possible explanations in this case, among them, inconsistencies in the time-depth conversion process associated with, for example, lateral velocity variations within the sedimentary pack.

By jointly comparing the resulting estimates of inversion of Scenarios 1 and 2a (Fig. 12a), we note that, despite the similarity between the estimated reliefs, it is noteworthy the presence of spurious features associated with "pinnacles" in the boreholes (Fig. 12 b). The comparison between the estimated reliefs in Scenarios 1 and $2 b$ (Fig. 12c), the surface corresponding to the difference between these estimates exhibits only minor anomalies possibly associated with the seismic reference model (Fig. 12d).

Moreover, the comparison between Scenarios 1 and 3 (Fig. 13a) shows similar responses differing mainly in the site of aggregate constraints (Fig. 13b). Regarding the comparison between the estimates obtained in Scenarios 2a and 3 (Fig. 13c), 


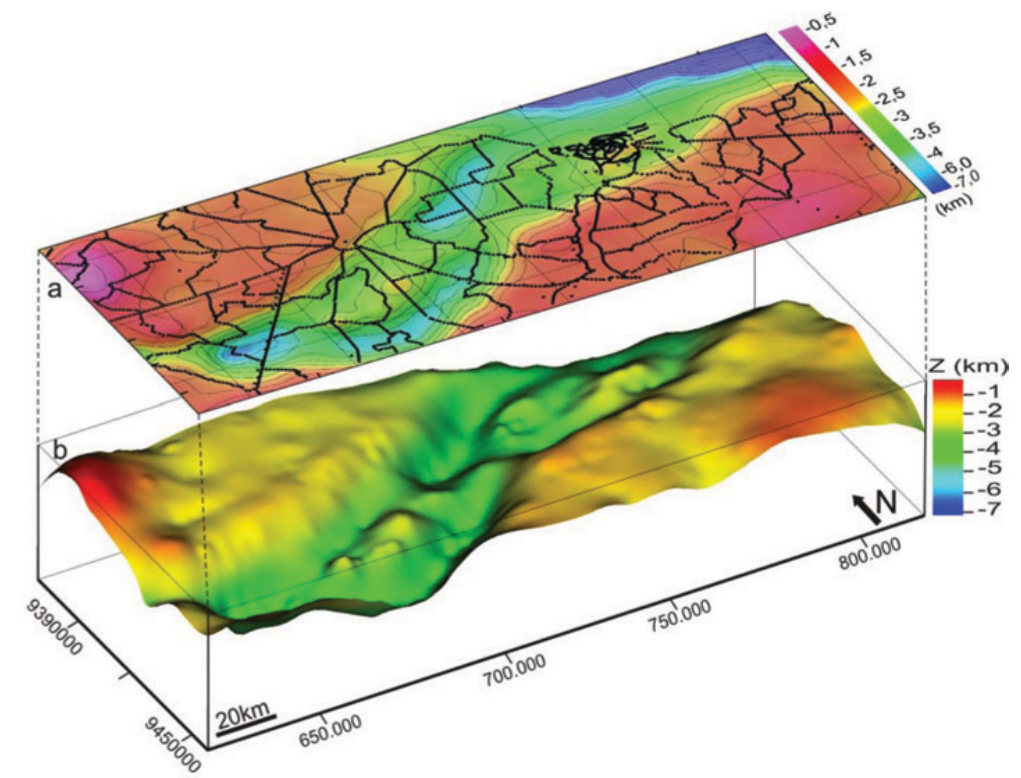

Figure 7 - Estimated basement relief of the onshore Potiguar Basin resulting from the gravimetric inversion performed in Scenario 1: a) contour map with the location of gravimetric stations (black dots), b) Perspective view with vertical exaggeration $8 \times$.

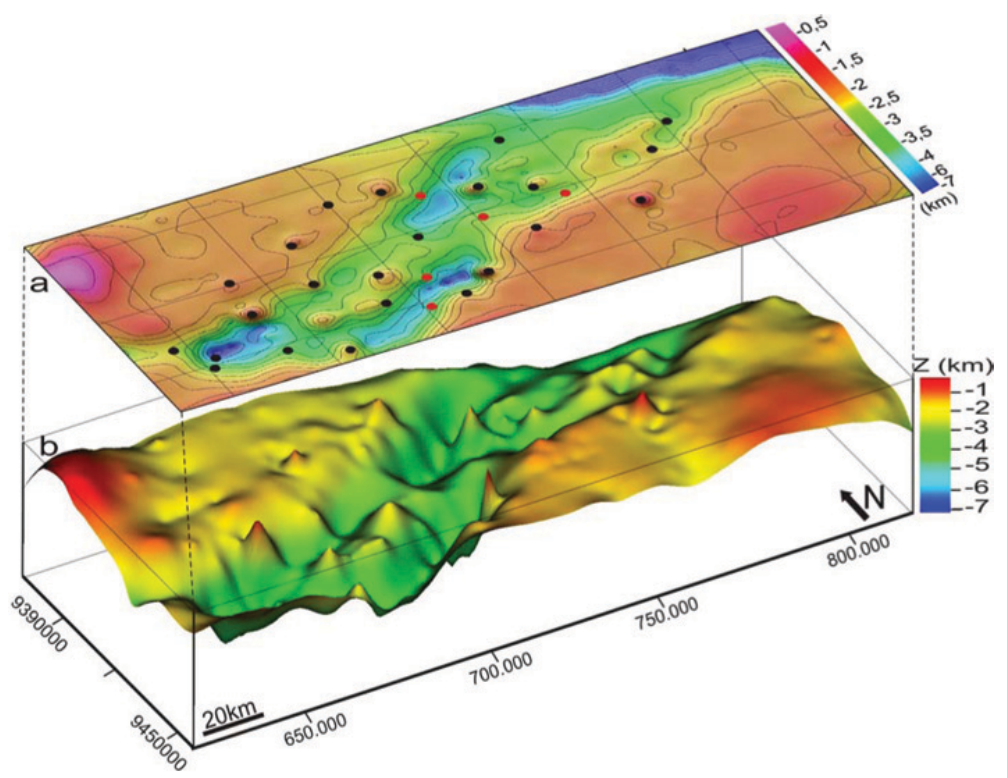

Figure 8 - Estimated basement relief of the onshore Potiguar Basin resulting from the gravimetric inversion performed in Scenario 2a: a) Contour map showing locations of wells completed in the basement (black circles) and wells ending in the sedimentary section (red circles), b) Perspective view with vertical exaggeration $8 \times$.

the surface of the resulting difference (Fig. 13d) reproduces the positions of the wells, highlighting two anomalies (yellow arrows in Figure 13d), which we believe represent two unusually shallow wells ending at the edge of the rift fault.
Finally, the comparison between the reliefs obtained in Scenarios $2 \mathrm{~b}$ and 3 (Fig. 13e) shows a striking similarity, since the anomalies seen on the surface of the differences (Fig. 13f) display low amplitude and reproduce the information of relief 


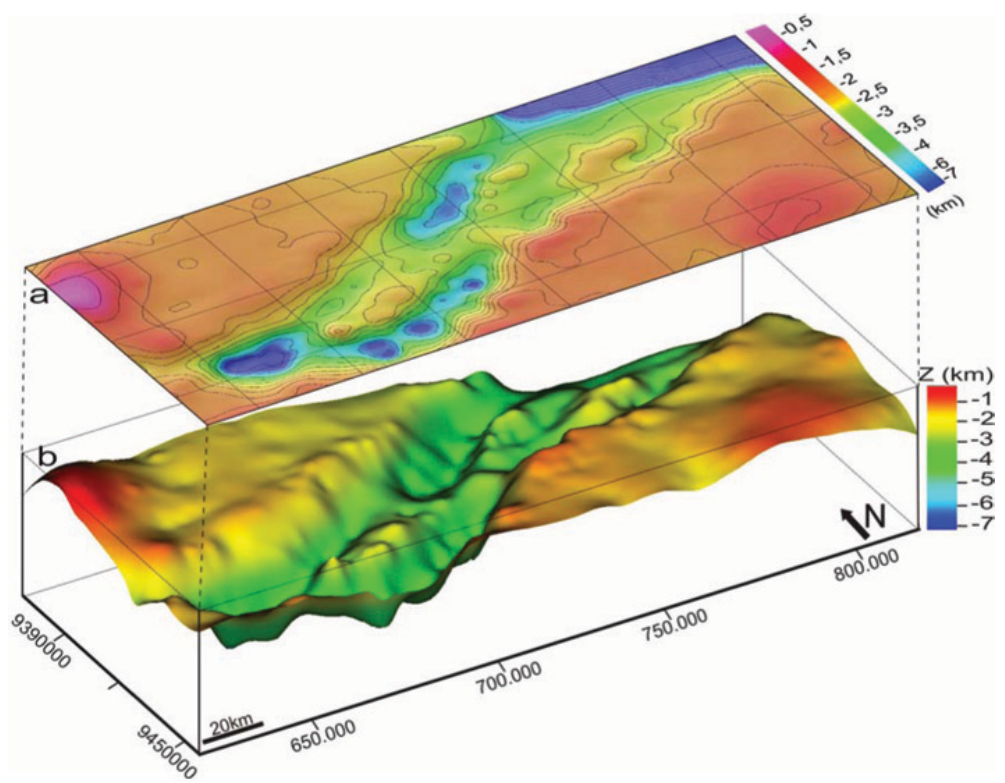

Figure 9 - Estimated basement relief of the onshore Potiguar Basin resulting from the gravimetric inversion performed in Scenario 2b: a) contour map, b) Perspective view with vertical exaggeration $8 x$.

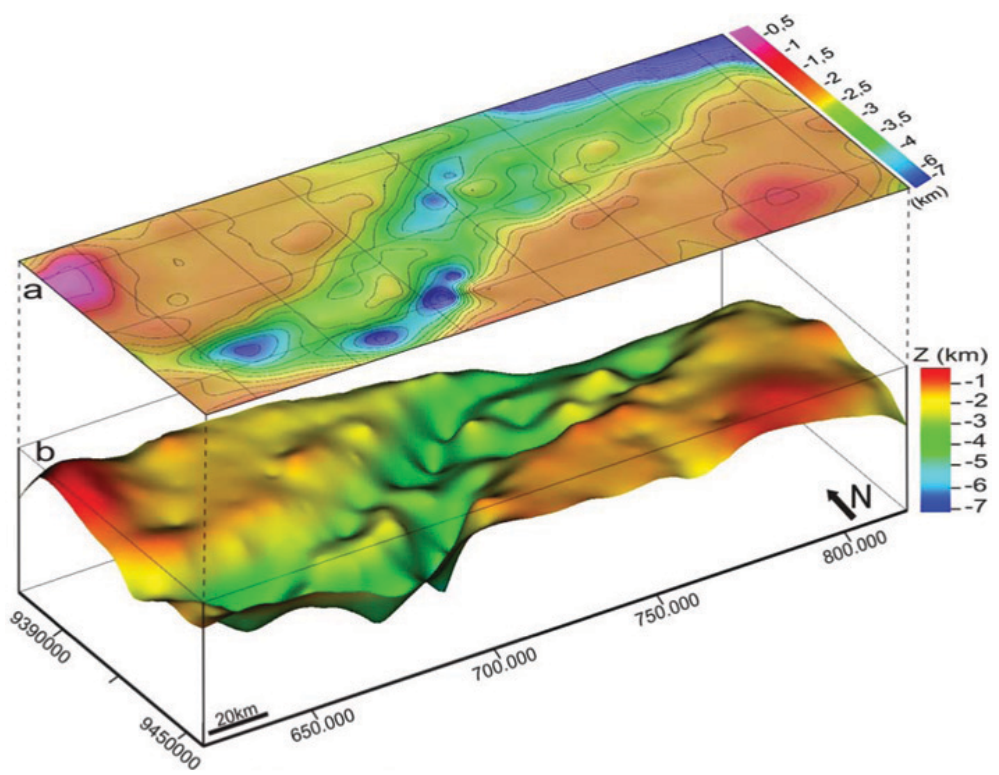

Figure 10 - Estimated basement relief of the onshore Potiguar Basin resulting from the gravimetric inversion performed in Scenario 3: a) contour map, b) Perspective view with vertical exaggeration $8 \times$.

variations aggregated by boreholes and the input model, but only locally (yellow arrows in Fig. 13f) at the same site already described in Figure 13d, but less evident (compare the scales of Figs. 13d and 13f).

Note then that, in general, in Scenario 3 the effect of "pinnacles" in the boreholes is reduced by the inversion process with the inclusion of a more accurate reference model. In this case, the borehole constraints helped to calibrate the depths, ensuring the effectiveness of the results with respect to the absolute values of the estimated depths. However, the gain in Scenario 1 compared to Scenario 3 was not as significant, since the regional features of the basin framework had already been defined in the gravity 


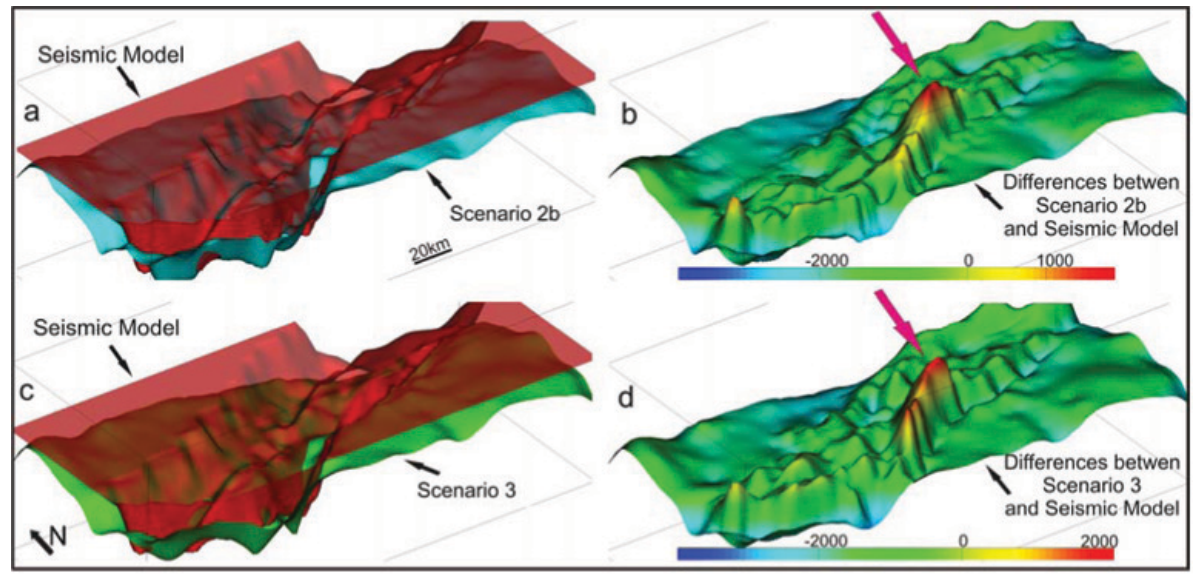

Figure 11 - Perspective views to compare the estimates of the basement relief of the onshore Potiguar Basin and seismic model: a) Overlap of the seismic model (red) and the estimate associated with Scenario $2 b$ (blue), b) surface corresponding to the difference between these two models, c) overlap of the seismic model (red) and the estimate associated with Scenario 3 (green), d) Surface referring to the differences between these two models. Observe the pink arrows showing the central-southeast region of the Carnaubais fault. Vertical exaggeration $8 \times$ in all perspectives.

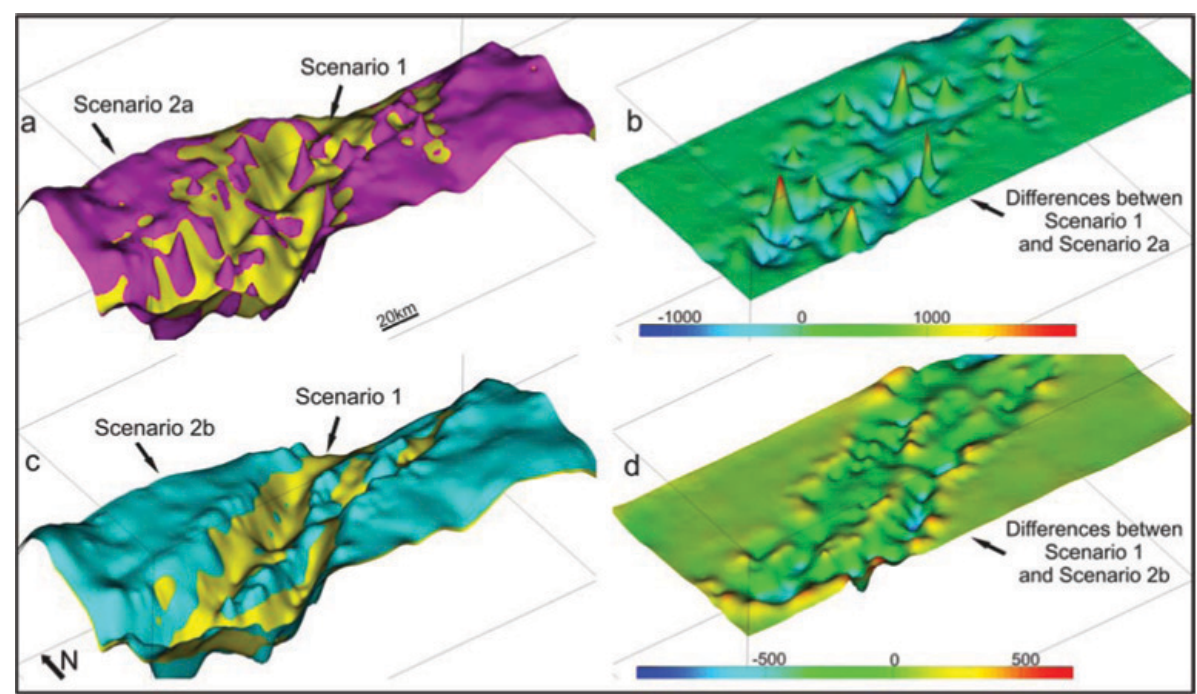

Figure 12 - Perspective views to compare the estimates of the basement relief of the onshore Potiguar Basin: a) overlap of the estimates associated with Scenario 1 (yellow) and the second (pink), b) surface corresponding to the difference between these two models, c) overlap of the estimates associated with Scenarios 1 (yellow) and $2 b$ (blue), d) surface corresponding to the differences between these two models. Vertical exaggeration $8 \times$ in all perspectives.

inversion associated with the first scenario. If we consider the low cost and low environmental impact characteristic of a gravity survey, we see that in terms of cost/benefit, the results obtained in Scenario 1 are significant and validate an extensive analysis of the gravity data in the initial exploratory phases.

\section{CONCLUSIONS}

In this work, gravimetric measurements and information from boreholes from seismic interpretation were combined simulat- ing three different scenarios or exploratory stages of the onshore Potiguar Basin over time. In the first scenario, only gravity data were used. In the second scenario, gravity data were combined first, with borehole constraints and second, with a seismic reference model for the basement. Finally, in the last scenario, gravimetric and borehole data and the seismic reference model for the basement were all combined.

The estimates obtained for the basement relief clearly revealed the basin framework in all scenarios. The main conclusion 


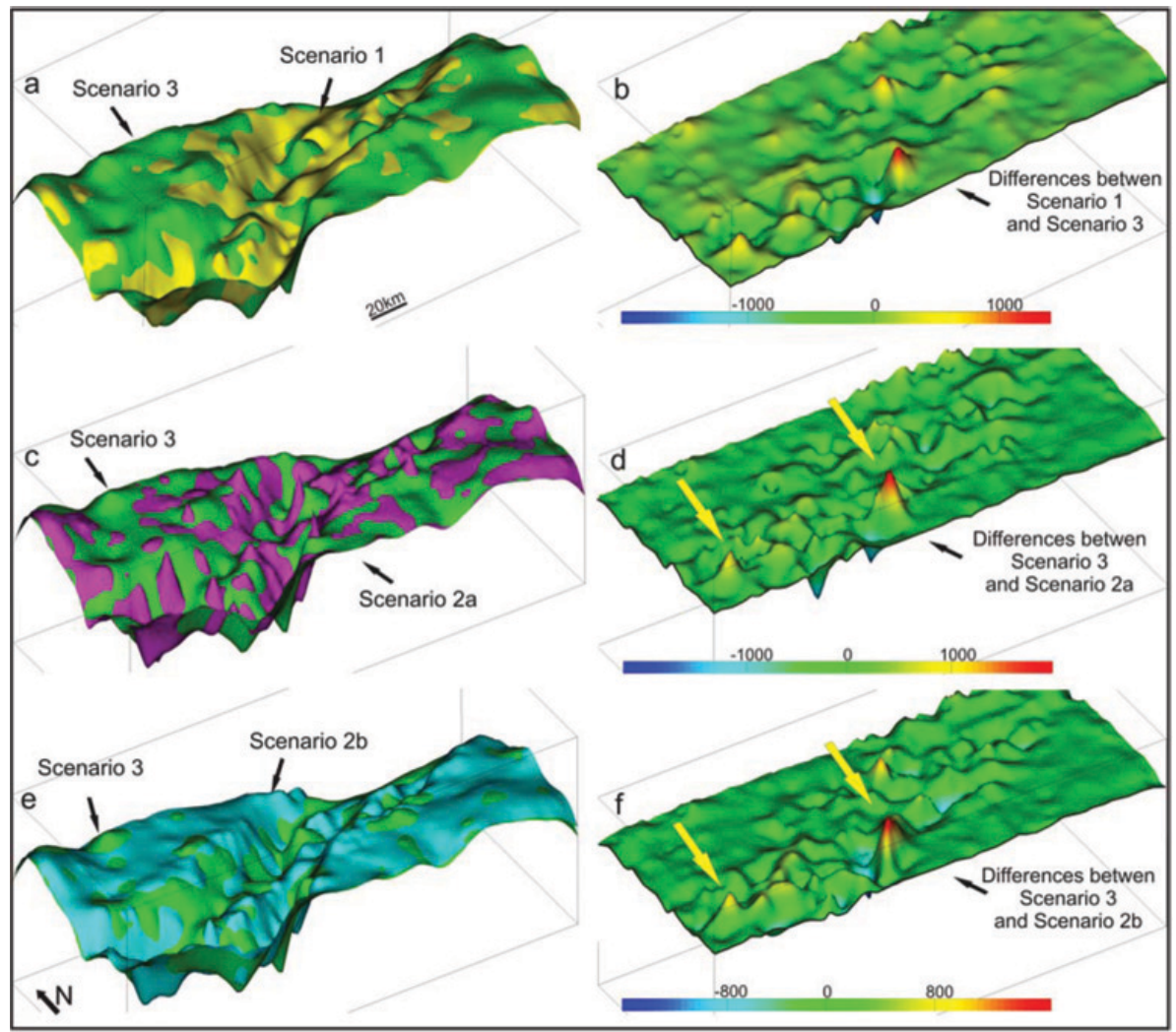

Figure 13 - Perspective views to compare the basement relief estimates of the onshore Potiguar Basin: a) overlap of the estimates associated with Scenario 1 (yellow) and 3 (green), b) surface corresponding to the difference between these two models, c) overlap of the estimates associated with Scenarios 2a (pink) and 3 (green), d) surface corresponding to the differences between these two respective models, e) overlap of the estimates associated with Scenarios $2 b$ (blue) and 3 (green), f) surface corresponding to the differences between these two models. Observe the arrows (yellow) probably referring to the boreholes located on the edge of faults. Vertical exaggeration $8 \times$ in all perspectives.

is that the most striking features of the structural framework of the basin have been well delineated in the inversion associated with Scenario 1. This is important, especially when taking into account the costs and the environmental impact of a gravity survey in relation to seismic survey or well drilling. The estimates obtained at later stages helped to enhance depth absolute values by increasing the resolution of the estimated relief, as additional information was added to the process.

Certainly, the basement relief of Scenario 3 estimated using borehole data and the seismic reference model is the most reliable because it is closer to the acceptable values for the area, not only in the rift region but also in the shallower portions of the basin.

It is noteworthy that, even when a basement relief obtained by the seismic interpretation is available; it is valid to estimate the relief based on the gravimetric inversion, because the discrepancies between the two methods can reveal inconsistencies in the assumptions used in the processing, such as intra- basement density variations, seismic quality problems or inconsistencies in the time-depth conversion process. Moreover, using gravity inversion coupled with borehole constraints and seismic model can ensure higher accuracy in the evaluation of a particular area, especially in cases where small discrepancies are found between the estimates derived from seismic and gravimetric interpretations. In this case, lack of inconsistency validates the hypothesis used independently to treat individually the data from each method.

\section{ACKNOWLEDGEMENTS}

The authors thank the Universidade Federal do Rio Grande do Norte for providing the gravity data and PETROBRAS for providing the InvGrav package used for the gravity inversion. Walter E. Medeiros thanks CNPq for the scholarship PQ (Process No. 304.301/2011-6) and associated grant. 


\section{REFERENCES}

BARBOSA VCF, SILVA JBC \& MEDEIROS WE. 1997. Gravity inversion of basement relief using approximate equality constraints on depth. Geophysics, 62(6): 1745-1757.

BARBOSA VCF, SILVA JBC \& MEDEIROS WE. 1999. Gravity inversion of a discontinuous relief stabilized by weighted smoothness constraints on depth. Geophysics, 64(5): 1429-1437.

BELTRÃO JF, SILVA JBC \& COSTA JC. 1991. Robust polynomial fitting method for regional gravity estimation. Geophysics, 56(1): 80-89.

LITINSKY VA. 1989. Concept of effective density. Key to gravity determinations for sedimentary basins. Geophysics, 54: 1474-1482.

LYRIO JCSO. 2002. Inversão não-linear de dados gravimétricos na Bacia do Recôncavo. In: VIII Simpósio de Geofísica da Petrobrás (008:2002, Vitória). Proccedings... Rio de Janeiro, Petrobrás. CD-ROM.

LYRIO JCSO. 2009. Processing and inversion of full tensor gravity gradiometry data. Faculty and the Board of Trustees of the Colorado School of Mines (USA) CSM Department of Geophysics, Number T6617, PhD Thesis. 244 pp.

MATOS RMD. 1987. Sistema de rifts Cretáceos do NE Brasileiro.
In: Seminário de Tectônica da PETROBRAS - PETROBRAS/CENPES/ DEPEX. Rio de Janeiro, Atas, 126-159.

MATOS RMD. 1992. Deep Seismic profiling, basin geometry and tectonic evolution of intracontinental rift basins in Brazil. Cornell University, Ithaca, New York (USA). Ph.D. Thesis 276 pp.

OLIVEIRA DC, MATOS RMD \& SOARES UM. 1993. Contribuição ao estudo das estruturas rasas na Bacia Potiguar: analise estrutural do afloramento de Afonso Bezerra (RN) e adjacências. In: SBG/Núcleo Bahia-Sergipe, Simp. Nac. de Estudos Tectônicos, 4, Belo Horizonte, 306-311.

OLIVEIRA RG. 2008. Arcabouço geofísico, isostasia e causas do magmatismo cenozóico da Província Borborema e de sua margem continental (Nordeste do Brasil). Natal: Universidade Federal do Rio Grande do Norte. Ph.D. Thesis, 441 pp.

PESSOA NETO OC, SOARES UM, SILVA JGF, ROESNER EH, FLORENCIO CP \& SOUZA CAV. 2007. Bacia Potiguar - Cartas Estratigráficas. Boletim de Geociências da PETROBRÁS, 15(2): 357-369.

SOARES UM, ROSSETTI EL \& CASSAB CT. 2003. Bacia Sedimentares Brasileiras: Bacia Potiguar. Phoenix, Aracajú, 5(56): 1-7.

Recebido em 16 maio, 2012 / Aceito em 12 novembro, 2012

Received on May 16, 2012 / Accepted on November 12, 2012

\section{NOTES ABOUT THE AUTHORS}

Marina Beatriz Gaino. Geologist (Universidade Estadual Paulista - UNESP, Rio Claro - 1988) and Master in Geophysics (Universidade Federal do Rio Grande do Norte - UFRN - 2012). Works with Geophysics at Petrobras since 1989, interpreting seismic/geological data in exploration of hydrocarbons. Main interests: seismic interpretation and potential methods, focusing on gravimetry.

Julio Cesar Soares de Oliveira Lyrio. Geologist (Universidade Federal do Rio de Janeiro - UFRJ - 1985) and Ph.D. in Geophysics from Colorado School of Mines (CSM) - USA, in 2009. Works as a geophysicist at Petrobras since 1987, analyzing and interpreting potential methods data. Main interests are gravity gradiometry, gravity inversion and researching new methodologies applied to the potential methods field.

Walter Eugênio de Medeiros. Civil Engineer (Universidade Federal do Rio Grande do Norte - UFRN - 1981), Master (UFBa - 1987) and Ph.D. in Geophysics (Universidade Federal do Pará - UFPA - 1993). Currently, works as a Professor in the Department of Geophysics UFRN and is the coordinator of undergraduate Geophysics, in conjunction with the graduate program in Geophysics and Geodynamics UFRN, as advisor in 10 masters and 6 doctoral degrees. Areas of interest are: applied geophysics (inverse problems, tectonophysics, assessment of exploration potential of sedimentary basins, prospecting for groundwater and shallow geophysics). He has published 32 articles in national and international journals and 1 textbook. Holds $1 \mathrm{~A}$ researcher position from CNPq and is a member of the editorial board of the Journal of Applied Geophysics and the Brazilian Journal of Geophysics. 